\title{
Semiology of Culture in James Joyce's A Portrait of the Artist as a Young Man
}

\author{
Leila Baradaran Jamili, Razie Arshadi*
}

Department of English Language and Literature, Faculty of Postgraduate Department of English Language and Literature, Islamic Azad University, Boroujerd Branch, Iran

Corresponding Author: Razie Arshadi , E-mail: raziearshadi2000@gmail.com

\section{ARTICLE INFO}

Article history

Received: March 15, 2018

Accepted: May 29, 2018

Published: August 31, 2018

Volume: 9 Issue: 4

Advance access: July 2018

Conflicts of interest: None

Funding: None

\section{Key words:}

City,

Culture,

Semiology,

Real City,

Fictional City

\begin{abstract}
This study sheds new light on the role of city whether real or fictional in modern novel as one of the signs of man's cultural fate. For the same reason, city is not a mere physical place, but a spatial concept. Not only has city become inseparable from man's personal and national destiny but also one's life continues to unfold on city's streets. James Joyce's (1882-1941) A Portrait of the Artist as a Young Man (A Portrait, 2000) deals with Joyce's home, Dublin. Joyce aims to universalize and simultaneously eternalize his home through his art. Accordingly, the reader of his text is to decipher the cultural signs of Dublin to get into it. As Michael Ryan (1946-) refers to culture as the total way of life that it has multiple meanings; to understand the culture of a city, to read its meaning, one has to decipher it. Semiology, based on Roland Barthes (1915-1980), is the science of signs whose emphasis is on the interpretation of codes, signs and symbols in a particular culture. Thus, the culture of Dubliners portrayed in A Portrait can be decoded through semiology by the readers. Stephen Dedalus is one who deciphers the cultural signs such as paralysis, religion, prostitution and confession through his walking in Dublin. He considers them as nets of Dublin that he tries to escape from them.
\end{abstract}

\section{INTRODUCTION}

There is a close relationship between city and culture. City can be examined as the representation of the pinnacle of human accomplishments in art work that is created by city itself. From the resemblance between the ideal city and the human soul in Plato's notion to Sigmund Freud's metaphor of Rome for the eternal laws of the mind, city's role has become remarkable in human life. Culture-capitals, such as Athens, Jerusalem, Alexandria, Rome, Vienna, Paris, London, New York, and Los Angeles, have long been looked to as symbols through which writers legalize their struggles for cultural authority.

This study makes visible the mixture of culture and history raised in the act of reading the representative fiction of Joyce as textual coding. In this regard, city is considered as a text. It is argued that Joyce's vision of the Irish capital goes beyond nationalism. In fact, he has got an internationalist perception of Ireland. He generates a powerful cultural manner of speaking that recreates the idea of the modernist city as a moral phenomenon in over-cultural and over-historical terms. Joyce's importance for cultural relations is underscored by his own struggle for Irish cultural authority.

Cities are as old as the term civilization; indeed, the critical mass arranged by city is more than any other phenome- non in comparison with other ones produced by civilization. Even the basic etymology of the word reveals its ancient past, for behind the English word city lies the Latin words civic (citizen) and civitas (citizenry, citizenship). Undeniably, humans have been reading cities in all sorts of ways since they generally agreed upon beginnings of civilization in Mesopotamia, circa 3500 BCE. When one reads cities he invariably raises questions about how cities come into being, how they take shape and grow, and what purposes they play in social, political and cultural changes. The city is the form and symbol of a combined social relationship where human experience modified practical and realistic signs, symbols, patterns of conduct, and systems of order.

One of the outcomes of modern literature is city novel. Desmond Harding, in Writing the City: Urban Visions \& Literary Modernism, divides city novel into three main types: "portrait", "ecological" and "synoptic" (7). Referring to his division, A Portrait can be considered as a city novel which belongs to the category of the portrait. In this type of novel, the city is revealed through the experiences of a single character, often a youth from the county. In this regard, Joyce's main character in A Portrait, Stephen Dedalus, is a young man who discloses Dublin through his experiences while he is walking in the streets of his home. 
Accordingly, the current study is mainly designed to reveal the relation between the author and the city. While the author walks through the streets of his or her home, he or she remaps it for the reader to make it familiar for him. In this way, Joyce takes the reader by himself through Dublin in $A$ Portrait to introduce it as the heart of the world. Hence, the leading methodology applied to the present study is semiology. The paper is based on the elaboration of the ideas of Roland Barthes concerning semiology, and the idea of cultural identity of Michael Ryan.

\section{METHODOLOGY}

City as the protagonist of modern novel is not treated exclusively as a physical place. The inhabitants' cultural fate is conditioned by city. Thus the reader examines it like a literary text and takes the advantage of semiology to shed new light on studying cities. As Richard Lehan states in The City in Literature (1998), "[t]he city has determined our cultural fate for the last three hundred years" (3). City is an inseparable part of our personal and national destiny. It can be considered as "the product of the Enlightenment, [while] urbanism is at the very heart of western culture. One can find books that touch upon the idea of the city as early as Plato's Republic and Augustine's City of God" (ibid). In modern literature, de facto, city has become the protagonist of the stories that is not a mere physical place.

Semiotics and semiology have become alternative names for the systematic study of signs. According to Bronwen Martin and Felizitas Ringham's definition in the Dictionary of Semiotics (2000), "semiotics is derived from the Greek word semion denoting "sign"" (1). The consideration of signs, indicators of meaning, is not limited to definite systems of communication such as language. The traffic signs and signals, and a great diversity of other human activities and productions such as bodily postures and gestures, the social rituals, the kinds of clothes, the meals, the buildings also indicate common meanings to members who participate in a particular culture, and they can be analyzed as signs which function in various modes of signifying systems.

Roland Barthes is one of the main prominent critics of semiology. He was the most brilliant and influential of the generation of literary critics who came to prominence in France in the 1960s. According to Barthes, in Elements of Semiology (1986), "semiology is the science of signs that its emphasis is on the interpretation of the codes, signs and symbols in a particular culture" (18). He states that, "signifier and signified are the components of the sign. Signified is not a thing but a mental representation of the thing" (ibid 35). In the social life of today there are to be found any extensive systems of signs outside human language. One should consider that the relationships between signifiers and signifieds within a particular language are arbitrary.

Barthes, in his Mythologies (1992), articulates that, "[s] emiology is a science of forms, since it studies significations apart from their content" (110). Any semiology postulates a relation between two terms, a signifier and a signified. The signifier expresses the signified, in any semiological system, not with two, but with three different terms. The signifier is empty, the sign is full, and it is a meaning. Naturally, there are functional implications between the signifier, the signified and the sign, such as that of the part to the whole.

Semiology is therefore destined to be absorbed into a trans-linguistics, the materials of which may be myth, narrative, journalism, or on the other hand objects of people's civilization, in so far they are spoken through press, prospectus, interview, conversation and perhaps even the inner language ruled by the laws of imagination. The object of a future semiology is the life of signs within society. Barthes' approach derives more from semiology than from semiotics-that is, more from the study of the life of signs within society. Where semiotics has seemingly been relegated to the academic department or the laboratory, semiology has increasingly engaged a variety of cultural phenomena ranging from fictional and non-fictional narratives to photography, advertising, clothing and food. Barthes states that, "the city is a discourse, and this discourse is actually a language: the city speaks to its inhabitants, we speak to our city, the city where we are, simply by inhabiting it, by traversing it, by looking at it" (ibid 417). If one considers the city as a writing, one, as the city's user, is a sort of reader. Accordingly, semiology is the way of reading the language of the city. Joyce identifies the image of the city in the readers of the city or in other words, the Dubliners. In this sense, he opens the world's eyes to Dublin.

Before proceeding to consider central Paris in semiotic terms, Barthes notes that in historical terms, the study of geographical space in general has always been characterized by relativism in terms of its denotation and study. For example, from the identification of human habitations in Greek antiquity in the maps of Anaximander and Hecataeus to the mental cartography of paradigmatic maps of the known world by Herodotus to Claude Levi Strauss's semiological study of an African Boro village, the nation of human spaces (geographical space) in western cultural history has always constituted a structurally grounded and contented discourse. In myth, there are two semiological systems, one of which is staggered in relation to the others, one should consider it that the relationships between signifiers and signifieds within a particular language are indeed arbitrary. As Barthes has argued, in Empire of Signs (1992):

[d] eciphering, normalizing, or tautological, the ways of interpretation, intended in the west to pierce meaning, i.e. to get into it by breaking and entering and not to shake it, to make it fall like the tooth of that ruminant of the absurd which the Zen apprentice must be, confronting his koan - cannot help failing the haiku; for the work of reading which is attached to it is to suspend language, not to provoke it. (72)

Being in another country means to act as a reader, not a visitor. This reader deals with cultural codes in the city. The more familiar meaning of the word culture is brought to light when one changes the idea into object. Thus culture becomes the object of reading and decoding.

Michael Ryan believes that culture either forms people's beliefs or transmits predefined concepts that exist as unquestionable and unchallengeable in society. He, in Cultural 
Studies (2010), defines 'culture' as it has always had multiple meanings. In one sense of the word, culture is inseparable from human life. Everything from how one dresses to what one eats, from how he speaks to what he thinks, is culture. Man only notices this really when he changes place and enters another culture. One feels it while he tries crossing a border, any border. Culture becomes visible when one travels between cultures and when he looks back in time to other 'cultures' than his own.

He declares that although culture is not internal, "[it] makes its way into us through our eyes and ears" (ibid 83). One learns the languages of culture as he grows up, for example what particular kinds of clothes mean, or what particular actions are good or bad or what words and attitudes are appropriate or not in what situations. The ways of understanding and methods of reasoning are acquired through culture that one uses to read the cultural world around him. In other words, the rules of life are internalized by culture which one grows up in it. Living in the place is like learning the dictionary that allows the meaning of its own cultural signs which makes it possible to be read, recognized, and deciphered.

\section{CULTURAL SIGNS IN A PORTRAIT OF THE ARTIST AS A YOUNG MAN}

As semiology seeks to elicit the real, its aim is to study the culture and the life of signs in society. Roland Barthes' Mythologies is model study of how meaning and values occur in everyday life. Indeed, Barthes collapses easy distinction between life and text into an ongoing field of Semiosis and meaning. In the case that the home is the first representation of universe, Joyce has chosen his home/Dublin to know it. He attains the knowledge of world through knowing his homeland. Stephen in A Portrait tries to recognize himself by setting an order from himself to universe:

He turned to the flyleaf of the geography and read what he had written there: himself, his name and where he was. Stephen Dedalus

Class of Elements

Clongowes Wood College

Sallins

County Kildare

Ireland

Europe

the World

the Universe. (A Portrait 12)

Whereas Joyce mapped the collective and individual histories of the urban cluster in terms of social, cultural, and political paralysis, the vision of his European metropolis does not ruin a progressive betterment over time of that vision, indeed of Joyce's unity with the city of Dublin. Joyce was haunted with the epistemology of the self-caught in the flux of international and universal history; but, like Stephen Dedalus, "he chronicled with patience what he saw, detaching himself from it and tasting its mortifying flavor in secret" (Harding 2003, p. 33).

Joyce is known as an ideal example of the modernist artist who organizes the conglomeration in art. Joyce, as an art- ist, disengages himself from political activity. The universe of Joyce's art is self-deciding and self-reflexive. The hero of his stories is city that is the supreme site of modern experience. Joyce always expounds on Dublin, because by getting to the heart of this city, he felt he could get to the heart of the considerable number of urban areas in history. Whereas the tendency of "Joyce-Dublin dialectic" does not present, a growing detachment from the nets of family, home, and religion (ibid). Rather, the further distance, time and space he puts between himself and his native city, the more complex Joyce has conception of himself as a self-exiled Irishman. Joyce in his Letters of James Joyce $(L)$, writes about Dublin to "betray the soul of that hemiplegia or paralysis which many consider a city" (L1:55). From within, Dublin is a diseased entity in Joyce's mind. Joyce believes that there is an evil as a universal principle of all human society, and is therefore able to construct a continuous parallel between the historical past and present to make the characters of modern Dublin representatives of the human condition. In fact, Joyce reconstructs Dublin based on its history.

According to Emer Nolan, Joyce's living and writing in heterogeneous cities such as Dublin, Trieste, Rome, Paris and Zurich during a period of historical revolution in Europe, constructed his internationalist vision of Dublin. The base of his vision was in two "interlocking and recursive" ways, including "a naturalistic, qualified, and knowable object" that was the representation of the "moral, cultural and social" objective of turn-of-the-century metropolitan Ireland. It was against "Celtic Twilight"'s nationalistic and romantic idea (1995, p. 36).

The politics of Joyce's fictions may be seen as a massive attempt to deconstruct the mythology of modern Ireland:

Joyce's Dublin and its inhabitants speak in universal terms to the sea change in human consciousness brought about by the expanding city, the city as labyrinth, and the city seemingly beyond the scale of human comprehension. Joyce's city fiction examines the dangers and possibilities of an urban polity and culture, and in doing so initiates new and enduring conversations between the present and the past about the future of the city. (Harding 2003, p. 123)

Joyce reveals through his Dublin that the growing city to what extent impacts on the way of changing in human consciousness. He illustrates how an urban culture can be dangerous. City in his writing is shown as a labyrinth that goes beyond human comprehension. In the first step, there are two sides of meaning of place - one is in the place itself and another is the sense of place which is in the viewer, cognized through subconscious reactions to knowing, through smell, touch and so on.

\section{Paralysis in a Portrait of the Artist as a Young Man}

Paralysis has become a leitmotif in Joyce's works that is one of the noticeable signs of Irish culture. Joyce considers Irish history as a form of paralyzed and diseased history. Harding, in Writing the City, states:

Joyce had written Dubliners as a chapter of the moral history of Ireland, and had chosen Dublin for that scene 
as the center of Irish cultural and social paralysis. In $A$ Portrait, Joyce returned to his native city, but with the cold promise to forge the uncreated conscience of my race, by way of exile for his artist-hero, Stephen Dedalus. In writing A Portrait, Joyce defines his moral history of Dublin as a step on the road to liberating Ireland. It is his personal experiences of contemporary Dublin centered on the lower-middle-class. (2003, p. 82)

Joyce aspires to achieve freedom and liberation in Ireland. He focuses his attention on Irish cultural and social paralysis and disability in his works. He experiences that situation, "Joyce establishes an imaginative topographical framework. In topographical terms, the narrator's mental journeying represents a series of concentric circles enclosing a nuclear core of deadening paralysis" (ibid 39). If culture operates as a kind of paralysis, it can prevent people from expressing themselves comfortably. It is concluded that Dublin's culture is the main cause of its paralysis which is widespread in Joyce's works. As a signifying system, Joyce's city feeds on itself, producing an endless chain of signification predicated on frustration and entrapment.

Stephen's description of city is rarely bright; i.e., he is conscious about the situation and in spite of the real paralyzed city he tries to save his own life from paralysis. The city is smoky and dusty:

the dim fabric of the city lay prone in haze. Like a scene on some vague arras, old as man's weariness, the image of the seventh city of Christendom was visible to him across the timeless air, no older nor more weary nor less patient of subjection than in the days of the thingmot. ( $A$ Portrait 146)

Joyce's narration of Dublin in A Portrait shows a gloom and darkened situation. He intentionally conceals the bright side of the city to the reader. His city is metaphorically supposed as a numb and motionless being. Since it is a place in which the time has been stopped for the inhabitants. They go round in circles, no beginning no ending. Stephen describes this paralyzed situation, "[s]o timeless seemed the grey warm air, so fluid and impersonal his own mood that all ages were as one to him. A moment before the ghost of the ancient kingdom of the Danes had looked forth through the vesture of the haze wrapped city" (A Portrait 148).

Dublin is an entropic landscape: terribly boring and terribly dull. Stephen's house is also an entropic and messy house. The gatherings in his house which mostly ended to political debates are like Dublin. Not surprisingly, characters look for adventures beyond the city. "To live, to err, to fall, to triumph, to recreate life out of life! A wild angel had appeared to him, the angel of mortal youth and beauty, an envoy from the fair courts of life, to throw open before him in an instant of ecstasy the gates of all the ways of error and glory" (A Portrait 152). He looks forward to meeting a new life out of home, in self-exile he tries to find life. "His eyelids trembled as if they felt the strange light of some new world. His soul was swooning into some new world, fantastic, dim, uncertain as undersea" (A Portrait 152).

Dublin suffers from cultural as well as political paralysis which becomes epidemic in Ireland's capital. Joyce decides that the only way to break paralysis is to flee from Ireland. In A Portrait, Stephen admits that "when a soul is born in Ireland, these are nets flung at it to hold it back from flight, you talk to me of religious, nationality and language, I will fly by those nets" (A Portrait 180). Stephen is the only conscious one in the circle of his Irish comrades who defines the traps of his home/Dublin. He knows that, to name just a few, religion, nationality and language become the obstacles that he should break them to become free.

\section{Religious Oscillation in a Portrait of the Artist as a Young Man}

As Clifford Geertz argues, in The Interpretation of Cultures, "[c]ulture denotes a historically transmitted pattern of meanings embodied in symbols, a system of inherited conceptions expressed in symbolic forms by means of which men communicate, perpetuate, and develop their knowledge about and attitudes toward life" (89). In other words, people's position in life is clarified by their culture. Geertz continues that religion is of considerable importance in culture. As far as James Joyce was educated by Jesuits, he was undoubtedly influenced by religion. A Portrait is a semi-autobiography of Joyce which in part reveals the influence of such religion on his life and his beliefs about life. Third chapter of A Portrait is dedicated to the history of Stephen's religious life. Although at the beginning of the story, there are long debates of Stephen's father and aunt Dante on religion, it becomes the parallel subject to nationalism. As a child, Stephen contemplates on the name of God, "God understood what all the people who prayed said in their different languages still God remained always the same God and God's real name was God" (A Portrait 27). Every night he prays God before going to bed. In this research one finds two kinds of Stephen's thoughts about religion. One is external and the other is internal. In this part of his life he himself challenges all the religious beliefs that he has been brought up with them, at home and at school.

He frequently debates to the priest about the concept of artist. He supposed himself as an artist whose responsibility is to save Dublin and Dubliners by his art. This shows the effect and the controlling power of religion on Dubliners. They cannot support their home and identity in front of religion. Religion and nationalism are the main topics of Stephen's and his schoolmate's discussions. The gipsy student says, "I admire the mind of man independent of all religions" (A Portrait 173). He wants to be free from the religious supervising. Stephen also thinks religion, language and nationality are obstacles on the way of the Irish generating and creating new life:

The soul is born, he said vaguely, first in those moments I told you of. It has a slow and dark birth, more mysterious than the birth of the body. When the soul of a man is born in this country there are nets flung at it to hold it back from flight. You talk to me of nationality, language, religion. I shall try to fly by those nets. Ireland is the old sow that eats her farrow. (A Portrait 177)

He argues that the souls of Irish people from the birth become disabled to flourish due to the hampers of Ire- 
land. These hampers are nationality, language, and religion which are parts of the Irish souls. The movement of Stephen's soul forward is unlike the Irish. He goes forth to experience and unfold itself "sin by $\sin$ " (A Portrait 91). Thus he stands against the religious rule that control Irish people's life, "banish from your minds all worldly thoughts and think only of the last things, judgment, hell and heaven" (A Portrait 103). The Irish mind is disabled by this religious rule. He lives a life full of anxiety and stress due to he does not want to suffer after his death. He is waiting on the Day of Judgment, "this day will come, shall come, must come; the day of death and the Day of Judgment," death is foremost than life for them, "death is certain. Death is the end of us all" (A Portrait 106). The Irish people consider their land as the realm of God's ire, Ireland the land of ire. They convince themselves that the fire of God is eternal.

Unlike other European countries in which the king usually plays the most powerful role in leading the land, Ireland is under the control of churchmen, "no king or emperor on this earth has the power of the priest of God. No angel or archangel in heaven, no saint, not even the Blessed Virgin herself has the power of a priest of God" (A Portrait 140). But Stephen cannot confine himself to religion. He does not want to feel that he is guilty all his life. The thought of converting comes to his mind:

The shadow, then, of the life of the college passed gravely over his consciousness. It was a grave and ordered and passionless life that awaited him, a life without material cares. The troubling odour of the long corridors of Clongowes came back to him. The chill and order of the life repelled him. His destiny was to be elusive of social or religious orders. The wisdom of the priest's appeal did not touch him to the quick. He was destined to learn his own wisdom apart from others or to learn the wisdom of others himself wandering among the trap of the world. (A Portrait 143-144)

The memories of his life in Clongowes is unpleasantly cold in his mind. He has been convinced that his fate is not to be a churchman. He eventually comes to the conclusion that his wisdom is superior to religion that confines him in a trap. Stephen's desires and self-understanding overcome the limitations, order, and rule that he decides he needs to move beyond in order to find a way to fly from the labyrinth.

\section{Prostitution in a Portrait of the Artist as a Young Man}

When the cultural situation that Joyce presents in A Portrait is discussed, prostitution and sexuality should be considered, too. Brown states that "[t]he word sexuality means pluralized sexualities," the preference is to use the plural form of the word since the singular form does not reveal the diversity of it, then heterosexuality, homosexuality, and bisexuality are forms of sexuality (2011, p. 37). In A Portrait, Stephen refers to these different matters. When he is the student in Clongowes School, one day some boys disappeared but a short while after it the boys were caught because of "smugging" that points to homosexuality:
The fellows looked at him and asked:

-Caught?

-What doing?

Athy said:

-Smugging.

All the fellows were silent: and Athy said:

-And that's why. (A Portrait 37)

Stephen clearly refers to prostitution in different places. According to Camilla Mount, in "Print Media and the Construction of the Public Sphere on James Joyce's Ulysses," "[t] he prostitute is symptomatic of the corrupted-public sphere," Joyce categorizes Dublin in A Portrait as "[t]he soul of the gallant venal city" (2014, p. 161). He concludes that the corruption is rooted in economical and cultural poverty. Dublin is either corrupted or paralyzed. The women are disabled mentally due to their suppression.

Interestingly, Stephen's first sin is sleeping with a whore and after that he supposes himself as a culprit who goes further step by step from God by doing sins:

The whores would be just coming out of their houses making ready for the night. He would pass by them calmly waiting for a sudden movement of his own will or a sudden call to his sin loving soul from their soft perfumed flesh.

-hello, Bertie, any good in your mind?

-Number Ten. Fresh Nelly is waiting on you. (A Portrait 96)

His bat like soul wakes to the consciousness of itself in darkness and secrecy and loneliness under the influence of the lenses, voices and gestures of a strange woman without guile. This strange woman is a sign of his barren culture.

\section{Confessional Culture in a Portrait of the Artist as a Young Man}

Requirement and habits of confession that inform characters' thinking and behavior are evident in A Portrait. Stephen Dedalus comes to maturity under the influences and effects of these restrictions. The narrative concerns simultaneously confession and Stephen's sexual desires and gendered ways of thinking as he moves toward what may or may not be greater freedom for himself as an individual and eventually for the Irish. These moments occur in each of the five parts, from the threatened punishment, if the child does not apologize to the young man's reconsidering his friendship with Cranly, who has acted as his confessor.

Confession is commonly considered as a religious issue that is the act of disclosing of sins to a priest in order to be given absolution. Though the reader does not deal with such a religious confession in the opening part, the threatening imperative to apologize contained in the vivid lines at the first part are the first indication of the confessional culture in which Stephen is growing up:

His mother said:

-O, Stephen will apologise.

Dante said:

$-\mathrm{O}$, if not, the eagles will come and pull out his eyes.

Pull out his eyes,

Apologise, 
Apologise,

Pull out his eyes.

Apologise,

Pull out his eyes,

Pull out his eyes,

Apologise. (A Portrait 4)

There is repeating violence and threat of violence against Stephen in words such as apologize that he hears many times at home. If he does not accept to apologize, he will be punished seriously. Stephen's experiences at the religious retreat in part three, which are physically and psychologically central to the narrative, result in the scene of Stephen's literal confession to a priest. Confession, desire, and freedom are also important, during the middle section of the climatic fourth part, when Stephen considers himself to become a priest. Stephen's decision parallels his later response to Cranly. His reaction to Cranly brings a confessional relationship to an end, but the dynamics of confession and desire will continue to have a significant effect on Stephen, as does his Catholic upbringing even after he turns aside from the priesthood.

According to John Paul Riquelme in "Desire, Freedom, and Confessional Culture in A Portrait of the Artist as a Young Man":

although his future artistic success is uncertain, at the end of the narrative by means of a trans gendering imagination Stephen changes the dynamics of confession. Rather than being captive to the confessional, he takes important steps towards achieving greater freedom. His new attitudes and behavior are a significant achievement. (2011, p. 38)

Confession paves the way of freedom for Stephen. $\mathrm{He}$ accomplishes a novel viewpoint and feeling which set his new life. Unpredictably, confession is not a trap for Joyce. $\mathrm{He}$ is not limited to churches' borders. Confession lets him think over his future life and make up his mind whether to be a priest or not.

\section{REAL AND FICTIONAL CITIES IN $A$ PORTRAIT OF THE ARTIST AS A YOUNG MAN}

Cities, as found in literature, on the one hand, are imaginative constructions; on the other hand, at least one literary city aims to reflect the material reality of its origin so accurately that from it the real city can be reconstructed. In this way Joyce believes that Dublin is an example of modern city and as he writes in a letter to Frank Budgen: "I want to give a picture of Dublin so complete that if the city one day suddenly disappeared from the earth it could be reconstructed out of my book" (ibid 21). It was his task to rebuild his home in his works by art.

According to Barthes, in $S / Z$ (1974), "[t]he narrative technique is impressionistic: it breaks up the signifier into particles of verbal matter which make sense only by coalescing. [...] The (ideological) goal of this technique is to naturalize meaning and thus to give credence to the reality of the story" (pp. 22- 23). In other words, the signifier is divided into smaller details of verbal matter through narration. It becomes sensible merely by fusing that makes the reality of the story acceptable. Umberto Eco (1932-2016), defines the narrative technique according to in Six Walks in the Fictional Woods (2004), as:

[t]here are two kinds of narrative: Natural and Artificial. Natural narrative describes events that actually occurred. Examples of natural narrative are: accounting of what happened to the narrator yesterday, a newspaper report, or even Gibbon's History of the Decline and Fall of the Roman Empire. On the other hand, artificial narrative is supposedly represented by fiction, which only pretends to tell the truth about the actual universe, or which claims to tell the truth about a fictional universe. The most obvious textual (that is, internal) signal of fictionality is an introductory formula such as "once upon a time. (P. 120)

In the case of James Joyce, he takes the advantage of artificial narrative to recreate a fictional Dublin. The reader is taken to the story by "once upon a time" (A Portrait 19). Eco asserts that:

[i]f fictional worlds are so comfortable; why not try to read the actual world as if it were a work of fiction. Or, if fictional worlds are so small and deceptively comfortable, why not try to devise fictional worlds that are as complex, contradictory, and provocative as the actual one? Let me answer the second question first: Dante, Rabelais, Shakespeare, Joyce indeed did this. (Eco 2004, p. 117)

The fictional worlds that have been created by great writers, seem to be as compound and sensual as the actual world. The real life is more similar to the life in novels. As Eco states, "fiction and life are transposed. In other words, to read life as fiction and to read fiction as life. Since fiction suggests a more comfortable context than life, one aims to read life as if it were a piece of fiction" (p. 118). The convenience of fiction persuades the man to shift from reality to fiction. Dublin is a fictional city based on Eco's definition. He states:

Dublin is not mentioned in A Portrait so today a researcher finds it but is not sure whether it describes a fragment of the real world or is a piece of fiction. Joyce enjoys reconstructing a city, a universe, the imaginary city. The world that is described, the inhabitants of that world, and the properties of both are the same, the researcher will simply map that representation onto reality. (Ibid 120)

The name Dublin is not stated directly in A Portrait; thus some researchers are uncertain about the real or fictional Dublin. But Joyce recreates the imaginary city which is possible to be mapped onto reality since he utilizes the elements of reality. In other words, that imaginary or fictional city in text is indicated through signs. There is a golden rule that code breakers rely on it, every secret message that is deciphered, it can eventually lead the researchers to map the reality based on the fiction. Eco believes that there is a problem that despite human's certainty about messages in fictional world, man is not sure about the message in actual world. Man is conscious of an authorial being behind the messages in fictional world that who is the creator $(2004$, p. 116). In 
this way, the author is the creator of the fictional world which rooted in his imagination.

Jeri Johnson, in "Literary geography: Joyce, Woolf and the City," concludes that, "in Joyce's works, cities were both "insistently themselves and persistently something other" (2000, p. 199). Joyce's theme in A Portrait is the realistic portrayal of the young Stephen Dedalus' struggle for life against the oppressive culture of home, church, and state, and of his transfiguration by the search for a transcendent idea of beauty. A Portrait continues to offer new and exciting surprises concerning the cultural and social forces transforming both the Irish and their metropolis at the turn of the century. A Portrait reveals the importance of Dublin for Joyce's fiction. It is not only a representation of the modern city as a singular outgrowth of aesthetic modernism but also a symptom of modernity itself.

In A Portrait, Stephen's burgeoning subjectivity and artistic development are caught in the inseparable tension between what can only be described as a sacred and profane relationship with the composition and consciousness of Dublin. "Consciousness of place came ebbing back to him slowly over a vast tract of time, unlit, unfelt, unlived. The squalid scene composed itself around him; the common accents, the burning gas jets in the shops, odors of fish and spirits and wet sawdust, moving men and women" (A Portrait 127). The real situation of Dublin comes by consciousness. Joyce's own project to map the moral history of Ireland is based on a close reading of Dublin. A Portrait's readers become familiar with real and fictional Dublin while they are wandering around Dublin.

By close reading of $A$ Portrait the trace of real Dublin is visible for the reader. Joyce names the real places which can be found on the map of Dublin. "He crossed the bridge over the stream of the Tolka" (A Portrait 144). Tolka is one of Dublin's three main rivers. "From the door of Byron's public house to the gate of Clontarf Chapel" (A Portrait 146). The Celtic church was founded in 1829 in north of Dublin. "He passed from the trembling bridge on to firm land again. [...] like a scene on some vague arras, old as man's weariness, the image of the seventh city of Christendom was visible to him" (A Portrait 148). The seventh city of Christendom refers to Dublin. "His morning walks across the city had begun: and he foreknew that as he passed the sloblands of Fairview he would think of the cloistral silver veined prose of Newman, that as he walked along the North Strand Road", it is a street in the North side of Dublin (A Portrait 154). "He was glad to find himself still in the midst of common lives, passing on his way amid the squalor and noise and sloth of the city fearlessly and with a light heart" (A Portrait 155).

Ordinary people are also widespread in Joyce's works. Stephen Dedalus, in A Portrait, lives with real people whom Joyce met in his real life. According to Ellmann, Davin, the peasant student is George Clancy in Joyce's real life, "Clancy appears in Joyce's early work as Madden who is called Davin in A Portrait" (1982, p. 61). In A Portrait, "Skeffington appears as Mccann," who was a less agile debater in fiction than he was in fact (ibid 62). Another real character mentioned by Ellmann is Byrne: "Joyce's close friendship at the college with John Francis Byrne, the Cranly of his novels" (ibid 63). Joyce himself in a letter to Grant Richards refers to the reality of characters in his work. He debates on invented comma and he wants to justify himself, "I think the commas used in English dialogue are given impression of unreality. He has this paradoxical view of Dublin, reality and unreality" (L1:75). In another letter, Joyce offered the manager of the Dublin house to hire a car and go round to the mentioned names then "show them the allusions and ask them whether they had any objection" (ibid). He means the real names that he mentions in A Portrait.

As Barthes states in Empire of Signs (1992), "[i]f I want to imagine a fictive nation, I can give it an invented name, treat it declaratively as a novelist object, create a new Garabagne, so as to compromise no real country by my fantasy (though it is then that fantasy itself I compromise by the signs of literature" (p. 3). In other words, writing a city by a novelist is an invention which is on the base of the novelist's imagination. It is not the exact copy of reality. The signs of literature are the writer's devices to accomplish his invention. In this way Joyce created a fictive nation to reveal the reality of it.

\section{CONCLUSION}

Since the discussion of this study is completely dedicated to the 'semiology' of city, it is concluded that the city is a text. City is not a museum of display, but it is a main part of life and culture of its inhabitants. To know a city, one should be a semiologist who acts as a cultural historian. The reader of city explores the culture of that land by deciphering different layers of its culture to elicit the meaning from it. Each object or concept has a special meaning in different cultures that is different from other place. Culture, as a set of rules of a society, is meaningful in that society. These rules are not stable and fixed. As time passes culture changes, too. Thus culture is not universal.

Joyce through his character, Stephen, acts as a fictional ethnographer who deciphers the Dubliners' culture. He tries to approach the meaning of each object or behavior beyond its surface. Hence he ponders on life of Dublin. At the beginning he defines the world through his five senses and while he becomes mature near to the end of the story he thinks and debates. An ethnographer should walk around the place. The act of walking can be considered as an instrument that helps the ethnographer. Stephen Dedalus walks around his home/ Ireland. Reading a city is reading a text. Cultural history of city is what the reader reads. The reader of the city is not an ordinary reader. He or she is a semiologist who deciphers the codes of city through semiology. He or she goes beyond the surface of city to elicit its meaning(s).

City in A Portrait is not an exact copied city of Dublin or real one. In other words, one faces two kinds of city, real and fictional. These two concepts, real and fictional, are inseparable. They overlap each other. The author is not a realist one at least in his writing. Joyce reveals the reality of city/Dublin by narrating a story. In fact, he recreates the image and signs of a real city or he is the creator of a fictional city. In this sense, Joyce leaves Ireland to write about it. 


\section{REFERENCES}

Barthes, R. (1992). Empire of Signs. Trans. Richard Howard. New York: Hill and Wang.

(1991). Mythologies. Trans. Annette Lavers. New York: The Nooday Press.

-----. (1974). S/Z. Trans. Richard Miller. New York: Blackwell.

-----. (1986). "Semiology and the Urban." The City and the Sign: An Introduction to Urban Semiotics. Ed. P.M. Gottdiener. New York: Colombia UP.

Brown, R, ed. (2011). A Companion to James Joyce. New York: Wiley-Blackwell.

Eco, U. (2004). Six Walks in the Fictional Woods. London: Harvard UP.

Ellmann, R. (1982). James Joyce. Oxford: Oxford UP.

Geertz, C. (1973). The Interpretation of Cultures. New York: Basic books.

Harding, D. (2003). Writing the City: Urban Visions \& Literary Modernism. London: Routledge.

Johnson, J. (2000) "Literary Geography: Joyce, Woolf and the City." City 4:2, 199-214.
Joyce, J. (1957). Letters of James Joyce. Vol. 1: 1904-1940. Ed. Stuart Gilbert. New York: Viking P.

-----. (1966). Letters of James Joyce. Vol. 2: 1882-1920. Ed. Richard Ellmann. New York: Vail- Ballou.

-----. (2000). A Portrait of the Artist as a Young Man. 2016.

Ed. Jeri Johnson. New York: Oxford UP.

McGarrigle, C. (2009). "Joyce Walks: Remapping Culture as

Tactical Space.” ISEA. Belfast.

www.conormcgarrigle.com/Joycewalks.html

Mount, C. (2014). "Print Media and the Construction of the

Public Sphere in James Joyce's Ulysses." Diss, U. of London.

Nolan, E. (1995). James Joyce and nationalism. London: Routledge.

Riquelme, JP. (2011). "Desire, Freedom and Confessional Culture in A Portrait of the Artist as a Young Man." A Companion to James Joyce, ed. Richard Brown. New York: Wiley-Blackwell, 34-53.

Ryan, M. (2010). Cultural Studies: A Practical Introduction. West Sussex: Willey-Blackwell. 